\title{
Use of horizontal flow roughing filtration in drinking water treatment
}

\author{
${ }^{1}$ A. Jafari Dastanaie; ${ }^{2}$ G. R. Nabi Bidhendi; ${ }^{2 *}$ T. Nasrabadi; ${ }^{3}$ R. Habibi; ${ }^{2}$ H. Hoveidi \\ ${ }^{1}$ Department of Civil Engineering, Islamic Azad University of Shahrekord, Shahrekord, Iran \\ ${ }^{2}$ Graduate Faculty of Environment, Tehran University, Tehran, Iran \\ ${ }^{3}$ Department of Environmental Engineering, Graduate School of the Environment and Energy, \\ Islamic Azad University, Science and Research Campus, Tehran, Iran \\ Received 7 November 2006; $\quad$ revised 8 May 2007; accepted 25 May 2007; available online 20 June 2007
}

\begin{abstract}
In order to evaluate the feasibility of implementation of horizontal-flow roughing filtration for drinking water treatment a pilot was designed and run at the bank of Zayandehroud river near the village of Chamkhalifeh. Pilot running was performed in summer 2003 (July, August and September), when the quality of river water was in relatively worst condition. The filter is comprised from three different parts which are separated with perforated baffles. Each compartment is filled with some local sand and gravel considering a special decreasing size regime. The overall function of the filter in removing turbidity and total suspended solids is acceptable. Additionally, iron, manganese and color and coliform removal are also been covered to some extent. Achieved results in this study shows that horizontal-flow roughing filtration may be considered as a packed, low-cost and efficient pretreatment process incase surface water is used as water supply for treatment. Furthermore, when small scale societies are considered and when no major pollutants exist in the water supply as the case in this study_ this system may be posed as a total treatment system, in which treated water exited from the filter may be sent to distribution network after a simple post chlorination.
\end{abstract}

Keywords: Horizontal flow roughing filtration, Chamkhalifeh village, Zayandehroud, surface water treatment

\section{INTRODUCTION}

Drinking water is supplied via surface and groundwater resources all around the world. Countries which are depended on surface water resources as drinking water supply are always encountered with high amounts of colloidal, dissolved and suspended solids in the bulk of raw water. Accordingly, total costs of conventional drinking water treatment process including initial, operation and maintenance costs have been always under debate in these regions, specially, in developing countries where supplying required chemicals as well as expert man power are posed as major controversial financial problems. This fact is more highlighted when we are dealing with small scale societies with low population where implementation of a multipart treatment system is not economically justified. Having the capability of simultaneous sedimentation and filtration, horizontal-flow rough filtration is an applicable alternative for supplying drinking water. On the contrary to slow and even rapid sand filters, horizontal-flow rough filters (HRFs) are not sensitive to high amount of turbidity and are able to

\footnotetext{
\*Corresponding Author Email: tnasrabadi@gmail.com

Tel.: +9821-6640 7719; Fax: +9821-6640 4647
}

function more than two months without the requirement of being backwashed. Roughing filters also have been studied by Evans (1999), Galvis, et al. (1994), Li, et al. (1996) and Wegelin (1994). Considering geographical texture of Iran, especially existence of various seasonal and permanent rivers, it is essential that the use of such packed systems be considered for supplying drinking water of towns and villages which are close to the bank of mentioned rivers.

\section{Study area}

Zayandehroud River exists in central water basin of Iran. Starting from Zagros Mountains, it meanders through mountainous and alluvial plains towards Gavekhuni marsh. Having the population of about 1000 people, Chamkhalifeh village is located in north-east of Cheharmahal-va-bakhtiari province in approximate $50^{\circ} 52^{\prime}$ east longitude and $32^{\circ} 30^{\prime}$ north latitude.

\section{MATERIALS AND METHODS}

In order to evaluate the feasibility of implementation of such system for drinking water treatment a pilot 


\section{A. Jafari Dastanaie, et al.}

was designed and run at the bank of Zayandehroud River near the village of Chamkhalifeh in 2003. In order to provide required head, the pilot was installed 2 meters below the elevation of river bed. Water was conducted towards the filter via a man made conduit. Design characteristics of the pilot are indicated in Table 1. The filter is comprised from three different parts which are separated with perforated baffles. Each compartment is filled with some local sand and gravel considering a special decreasing size regime. In other words, the diameter of stuffs in the compartments is decreased from $25-15 \mathrm{~mm}$ in the first compartment to $15-8 \mathrm{~mm}$ in the second and 8-4 in the last one. The average height of materials in the filter is 2.5 meter and water always undergoes a subsurface flow beneath the surface of the filter. Typical filtration rates for roughing filters are between 0.3 and $1.5 \mathrm{~m} / \mathrm{h}$ (Hendricks 1991) and typical gravel sizes may be as large as $40 \mathrm{~mm}$ and as small as 3 $\mathrm{mm}$. For additional information, readers are referred to Kuehn and Mueller (2000) and Ray, et al., (2002). These papers demonstrate the complexities of riverbank filtration and reveal the need for special expertise if use of riverbank filtration is contemplated in conjunction with filter plant. Pilot running was performed in summer 2003 (July, August and September), when the quality of river water was in relatively worst condition.

\section{RESULTS}

In order to monitor the quality of outlet water, parameters like total suspended solids (TSS), turbidity, color and fecal coliforms as well as ions like iron and manganese are being compared between inlet and outlet water. The comparison between the values of mentioned parameters in inlet and outlet water is illustrated in Figs. 1 to 4 . As it is shown in the figures, the overall function of the filter in removing turbidity and TSS is acceptable. Additionally, iron, manganese and color removal are also been covered to some extent. The variation of coliform pollution in inlet and outlet water is also monitored. Microorganism removal improves with lower filtration rates and with smaller sand size in the filter bed. Bellamy et al. (1985) observed total coliform removal of greater than98 \% for $0.29 \mathrm{~mm}$ effective size sand versus $96 \%$ removal for $0.62 \mathrm{~mm}$ effective size sand for filters having the same bed depth and filtration rate. Average concentrations as well as removal efficiency of different are shown in Table 2.

\section{DISCUSSION AND CONCLUSION}

Financially, dealing with surface water as water supply has always been a remarkable factor. Considering removal efficiency of 94, 89.7, 64, 63.4, 20 and $15.6 \%$ for coliform pollution, total suspended solids (TSS), manganese, turbidity, color and iron respectively, this system has shown convincible results. Achieved results in this study shows that horizontal-flow roughing filtration may be considered as a packed, low-cost and efficient pre treatment process incase surface water is used as water supply for treatment. Furthermore, when small scale societies are considered and when no major pollutants exist in

Table1: Characteristics of the pilot horizontal-flow roughing filter

\begin{tabular}{|c|c|c|c|c|c|c|c|}
\hline \multirow{2}{*}{ Parameter } & \multirow{2}{*}{$\begin{array}{l}\text { Required } \\
\text { water }\end{array}$} & \multirow{2}{*}{ Filtration rate } & \multirow{2}{*}{ Water depth } & \multirow{2}{*}{ Width } & \multicolumn{3}{|c|}{ Length of compartments } \\
\hline & & & & & First & Second & Third \\
\hline Unit & $\mathrm{L} / \mathrm{sec}$ & $\mathrm{m} / \mathrm{h}$ & $\mathrm{m}$ & $\mathrm{m}$ & $\mathrm{m}$ & $\mathrm{m}$ & $\mathrm{m}$ \\
\hline Value & 3.5 & 1.8 & 2 & 5 & 3 & 2.30 & 1.80 \\
\hline
\end{tabular}

Table 2: Removal efficiencies of the filter for particular parameters

\begin{tabular}{lllll}
\hline Parameter & Unit & Inlet & Outlet & Removal Efficiency \% \\
\hline Turbidity & NTU & 3.528 & 1.29 & 63.4 \\
Color & $\mathrm{mg} / \mathrm{L}$ & 0.8 & 0.6 & 20 \\
Iron & $\mathrm{mg} / \mathrm{L}$ & 0.083 & 0.07 & 15.6 \\
Manganese & $\mathrm{mg} / \mathrm{L}$ & 0.0417 & 0.015 & 64 \\
TSS & $\mathrm{mg} / \mathrm{L}$ & 18.93 & 1.95 & 89.7 \\
Coliforms & $\mathrm{MPN}$ & 112.6 & 6.74 & 94 \\
\hline
\end{tabular}




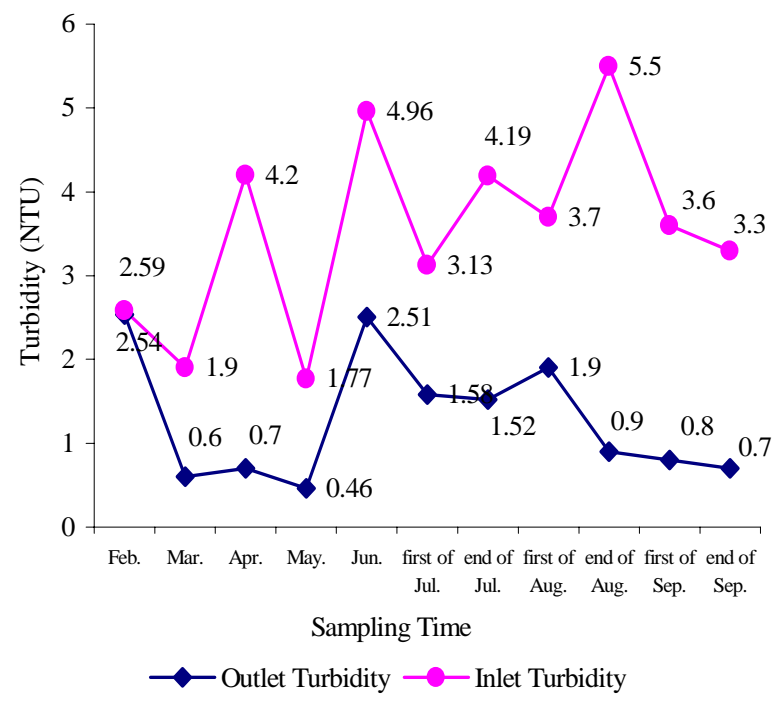

Fig. 1: Variation of turbidity value in inlet and outlet water through the pilot

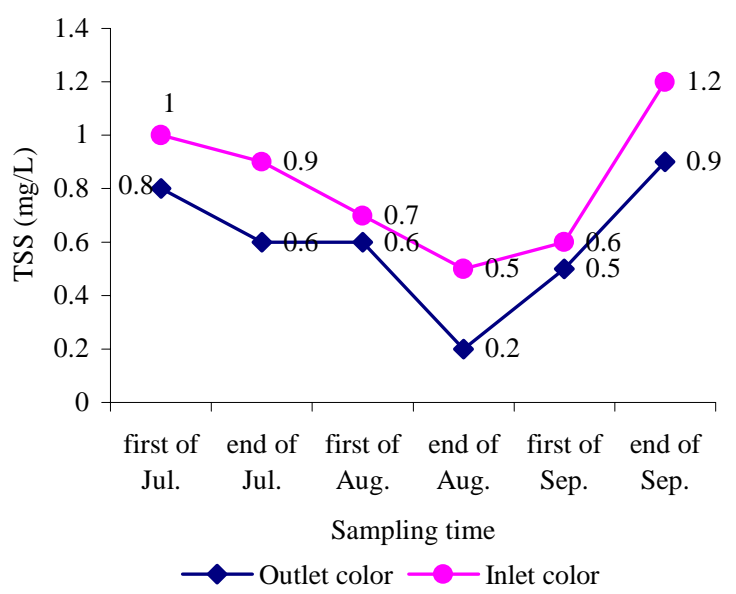

Fig. 3: Variation of iron and manganese value in inlet and outlet water through the pilot

the water supply as the case in this study. This system may be posed as a total treatment system, in which treated water exited from the filter may be sent to distribution network after a simple post chlorination. Lowering the rate of filtration by $1 \mathrm{~m} / \mathrm{h}$ or even less and increasing the length of filter is suggested for gaining more removal efficiencies in case of more pollution existence. Keeping this package indoors is highly recommended in order to prevent inconveniences caused by wind, precipitation, etc.

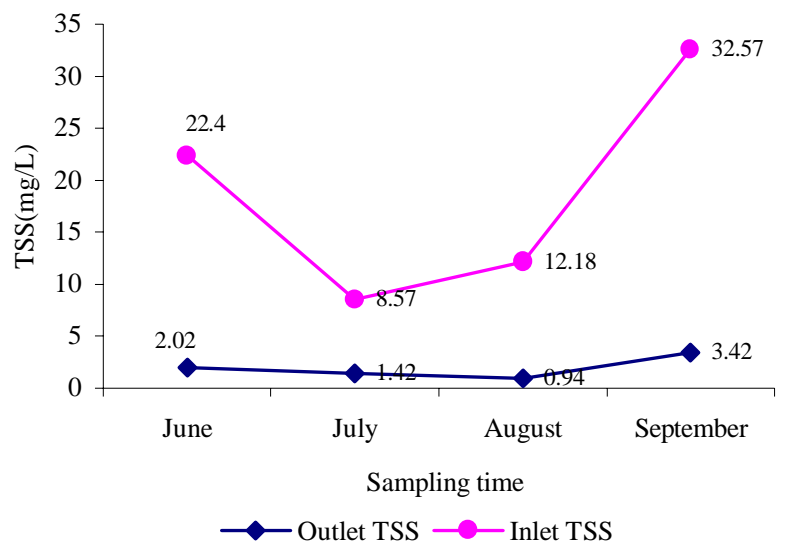

Fig. 2: Variation of total suspended solids (TSS) value in inlet and outlet water through the pilot

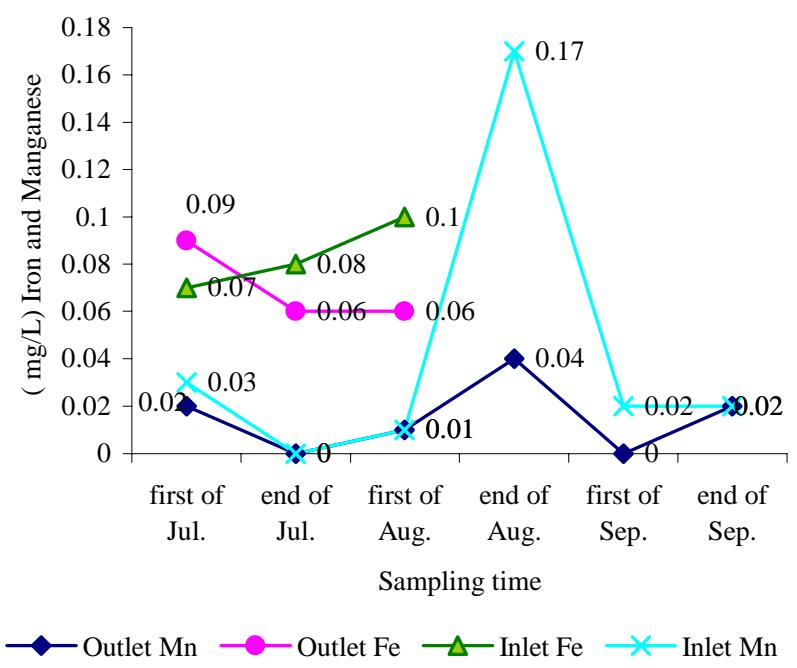

Fig. 4: Variation of color value in inlet and outlet water through the pilot

\section{REFERENCES}

Bellamy,W.D.; Hendricks, D.W. and Logsdon, G.S., (1985). Slows and filtration: influences of selected process variables. J. Am. Water Works Assoc., 77(12), 62-66.

Evans, H.L., (1999). Portfolio submitted for part fulfillment of the degree of Engineering Doctorate in Environmental Technology. University of Surrey, Guildford, Surrey, U.K.

Galvis, G.; Visscher, J.T. and Lloyd, B.J., (1994). Section 3.1. Overcoming water quality limitations with the multi-barrier concept: a case study from Columbia. In Slow sand filtration: an international compilation of recent scientific and operational developments. American Water Works Association, Denver, Co. 47-60. 
Use of horizontal flow roughing filtration in drinking water..

Hendricks, D.W., (1991). Manual of design for slow sand filtration. American Water Works Association Research Foundation, Denver, Co.

Kuehn,W. and Mueller, U. (2000). Riverbank filtration: an overview. J. Am.Water Works Assoc., 92 (12), 60-69.

Li, G.B.; Ma, J. and Du, K.Y., (1996). Multi-stage slow sand filtration for the treatment of high turbid water. In Advances in slow sand and alternative biological filtration. Edited by N. Graham and R. Collins. John Wiley and Sons, New York. 371-378.

Ray, C.; Grischek, T.; Schubert, J.; Wang, J. and Speth, T. (2002). A perspective of riverbank filtration. J. Am. Water Works Assoc., 94(4), 149-160.

U.S. Environmental Protection Agency, (EPA), (1990). Technologies for upgrading existing or designing new drinking water treatment facilities. EPA/625/4-89/023. Office of Drinking Water, U.S. Environmental Protection Agency, Cincinnati, Ohio.

Wegelin, M., (1994). Section 3.2. Roughing filters for surface water pretreatment. In Slow sand filtration: an international compilation of recent scientific and operational developments. American Water Works Association, Denver, Co. 61-75.

Wegelin, M. and Mbwette, T.S.A., (1989). Horizontal-flow roughing filtration. In Pre-treatment methods for community water supply. Edited by J.E.M. Smet and J.T. Visscher. International Reference Centre for Community Water Supply and Sanitation, The Hague, The Netherlands. 127-156.

\section{AUTHOR (S) BIOSKETCHES}

Jafari Dastanai, A., M.Sc., instructor, Department of Civil Engineering, Islamic Azad University of Shahrekord, Shahrekord, Iran. Email: gafari_abas@yahoo.com

Nabi Bidhendi, G. R., Ph.D., is an associate professor in the Graduate Faculty of the Environment, University of Tehran, Tehran, Iran. Email: ghhendi@ut.ac.ir

Nasrabadi, T., P.hD. student in environmental engineering at the Graduate Faculty of the Environment, University of Tehran. Tehran, Iran. Email: t_nasrabadi@yahoo.com

Hoveidi, H., P.hD. student in environmental planning at the Graduate Faculty of the Environment, University of Tehran. Tehran, Iran. Email: hoveidi10@yahoo.com

Habibi, R., M.Sc., Faculty of the Environment and Energy, Islamic Azad University, Science and Research Campus, Hesarak, Pounak, Tehran, Iran.Email:srn_habibi@yahoo.com 